\title{
Aggregate size and glucose level affect priming sources: A three- source-partitioning study
}

\author{
Jing Tian ${ }^{\text {a, b, * }}$, Johanna Pausch ${ }^{\text {b }}$, Guirui Yu ${ }^{\text {a }}$, Evgenia Blagodatskaya ${ }^{\text {b, d, **, }}$, \\ Yakov Kuzyakov b, c \\ a Key Laboratory of Ecosystem Network Observation and Modeling, Institute of Geographic Sciences and Natural Resources Research, Chinese Academy of \\ Sciences (CAS), 100101, Beijing, China \\ ${ }^{\mathrm{b}}$ Department of Soil Science of Temperate Ecosystems, University of Göttingen, 37077, Göttingen, Germany \\ ${ }^{c}$ Department of Agricultural Soil Science, University of Göttingen, 37077, Göttingen, Germany \\ d Institute of Physicochemical and Biological Problems in Soil Science, Russian Academy of Sciences, 142290, Pushchino, Russia
}

\section{A R T I C L E I N F O}

\section{Article history:}

Received 12 January 2016

Received in revised form

22 March 2016

Accepted 24 March 2016

Available online 4 April 2016

\section{Keywords:}

Aggregate size classes

Priming effect

Isotopic approach

${ }^{14} \mathrm{C}$-labeled glucose

$\mathrm{C}_{3} / \mathrm{C}_{4}$ vegetation change

$\mathrm{C}$ sequestration

\begin{abstract}
A B S T R A C T
Decomposition of soil organic matter (SOM) protected within aggregates can be accelerated via priming effect (PE) by the addition of fresh substrates. However, the knowledge of the sources of mineralization and $\mathrm{PE}$ in aggregate size classes is absent. We applied the three-source-partitioning isotopic $\left({ }^{14} \mathrm{C}+\delta^{13} \mathrm{C}\right)$ approach to determine how aggregate size classes affect the contribution of three $\mathrm{C}$ sources (substrate added, recent and old SOM) to $\mathrm{CO}_{2}$ efflux and PE depending on the amount of added primer. Soil from a field with 3 years of maize cropping ( $C_{4}$ plants) after long-term $C_{3}$ vegetation was used to differentiate between recent $C\left(C_{4}-C ;<3\right.$ years $)$ and old $C\left(C_{3}-C ;>3\right.$ years $)$. Soil samples were separated into three aggregate size classes ( $>2 \mathrm{~mm}, 2-0.25 \mathrm{~mm}$ macroaggregates and $<0.25 \mathrm{~mm}$ microaggregates) and were incubated for 49 days after being amended with two levels of ${ }^{14} \mathrm{C}$ labeled glucose.

The proportion of glucose mineralized to $\mathrm{CO}_{2}$ increased with decreasing aggregate size, but ${ }^{14} \mathrm{C}$ incorporation into microbial biomass decreased, indicating higher $C$ use efficiency in macroaggregates compared with microaggregates. The short-time PE was positive and was accompanied by a rapid reduction of dissolved organic C. After 49 days, the PE was higher in macro-versus microaggregates at both glucose levels. Positive PE induced by a low glucose level was observed only in large macroaggregates $(>2 \mathrm{~mm})$, but was observed in both macroaggregates $(>0.25 \mathrm{~mm})$ and microaggregates $(<0.25 \mathrm{~mm})$ after high glucose amendment. These results indicate that SOM pools are more decomposable in macro-versus microaggregates and that the SOM pools are involved in PE according to their biochemical availability. More primed $\mathrm{CO}_{2}$ originated from recent $\mathrm{C}_{4}-\mathrm{C}$ than old $\mathrm{C}_{3}-\mathrm{C}$ in larger macroaggregates under a low glucose level. The relative contribution of recent $\mathrm{C}_{4}-\mathrm{C}$ to primed $\mathrm{CO}_{2}$ increased from macroaggregates (37.8\%) to microaggregates (100\%) after high glucose amendment. Therefore, increasing glucose addition stimulated the decomposition of old $C_{3}-C$ in macroaggregates, but not in microaggregates. This indicates that microaggregates protect SOM against decomposition better than macroaggregates, and consequently, microaggregates can be considered as a potential reservoir for longterm $C$ sequestration.

Concluding, aggregate size is crucial for SOM decomposition, and it determines the source of PE and thus the protection of sequestrated $C$. The effects of the added primer on $C$ sources involved in PE depend on the aggregate size.
\end{abstract}

(C) 2016 Elsevier Ltd. All rights reserved.

\footnotetext{
* Corresponding author. Key Laboratory of Ecosystem Network Observation and Modeling, Institute of Geographic Sciences and Natural Resources Research, Chinese Academy of Sciences (CAS), 100101, Beijing, China.

** Corresponding author. Department of Soil Science of Temperate Ecosystems, University of Göttingen, 37077, Göttingen, Germany.

E-mail addresses: tianj@igsnrr.ac.cn (J. Tian), janeblag@mail.ru (E. Blagodatskaya).
}

\section{Introduction}

The input of readily available substrates to the soil can alter carbon (C) sequestration by modifying the mineralization of the native soil organic matter (SOM) pool via priming effect (PE) (Kuzyakov, 2010). The SOM is not chemically uniform and consists 
of various pools with varying levels of degradability and turnover rates (Stevenson, 1994; Von Lützow et al., 2007). Therefore, it is important to consider the contribution of individual SOM pools to $\mathrm{CO}_{2}$ release and to investigate the extent to which various pools are involved in PE.

Soil organic matter occlusion within aggregates is one of the most important physical preservation mechanisms because there are physical barriers between microorganisms, enzymes and their substrates (Six et al., 2002). Using the "aggregate hierarchy" hypothesis, it is generally accepted that microaggregates $(<0.25 \mathrm{~mm})$ can afford the most protection to associated SOM. This is because the SOM associated with microaggregates is formed by primary particles coupled together by plant and microbial debris and by humic materials or polysaccharide polymers, which better protect SOM against decomposition than macroaggregates $(>0.25 \mathrm{~mm}$ ) (Elliott, 1986; Six et al., 2002; Denef et al., 2007; Kimura et al., 2012). Additionally, SOM preferentially stabilized in microaggregates can be better protected against decomposition within stable macroaggregates (Six et al., 2000; Six and Paustian, 2013). Turnover of SOM is assumed to be more rapid in macroaggregates than in microaggregates (Besnard et al., 1996; Six et al., 2002; Gunina and Kuzyakov, 2014). This assumption was confirmed with more SOM mineralized from macroaggregates ( $>0.25 \mathrm{um}$ ) versus microaggregates $(<0.25 \mathrm{~mm})$ (Gregorich et al., 1989; Mutuo et al., 2006), with higher PE also observed in macroaggregates (>0.25 um) compared with microaggregates $(<0.25 \mathrm{~mm}$ ) (Tian et al., 2015). However, there is no consensus on the effects of aggregate size classes on SOM decomposition because the greatest $\mathrm{CO}_{2}$ production is from the microaggregates (Seech and Beauchamp, 1988; Drury et al., 2004; Sey et al., 2008), and no differences between macro- and microaggregates have been reported (Rabbi et al., 2014). Furthermore, an increase in PE intensity with decreasing particle size has been observed, which has shown not only that the labile pools in aggregates are affected but also that more stable pools are characterized by higher ${ }^{14} \mathrm{C}$ ages (Ohm et al., 2007; Negassa et al., 2015).

To identify the SOM pools responsible for mineralization and PE, more than two C sources should be labeled (Kuzyakov, 2010). Despite recent progress in the partitioning of three $C$ sources (added substrate, recent and old C) in SOM (Kuzyakov and Bol, 2006; Fontaine et al., 2007; Blagodatskaya et al., 2011, 2014; Derrien et al., 2014), there is still a lack of information on such partitioning within aggregate size classes.

Generally, a positive correlation between the amount of an added labile substance and its microbial mineralization has been observed (Bremer and van Kessel, 1990; Mary et al., 1993; Schneckenberger et al., 2008). In addition, it has been shown that the priming of SOM decomposition increased with the increased addition of labile substrates until saturation of the microbial utilization capacity (Blagodatskaya and Kuzyakov, 2008; Paterson and Sim, 2013). However, it is not only the labile pools of SOM that are easily affected by PE, but also the SOM pools with low degradability (Hamer and Marschner, 2005). The SOC fractions with low degradability can be affected by PE after repeated substrate inputs (Fontaine et al., 2007; Mau et al., 2015) and high amounts of primer (Blagodatskaya et al., 2011). In addition to the recalcitrance of SOM pools, all these studies have suggested that the availability of the primer is a limitation for the degrading microorganisms and that this is a major factor controlling the extent of SOM decomposition.

We hypothesized that (1) more $C$ would be mineralized and a higher PE would be observed in macroaggregates because SOM is less recalcitrant and more easily decomposable than in microaggregates (Elliott, 1986; Six et al., 2002; Denef et al., 2007) and, consequently, the SOM pools involved in PE vary according to their biochemical availability (Blagodatskaya et al., 2011); (2) compared with macroaggregates, the PE in microaggregates would require higher levels of primer addition; (3) the relative contribution of recent $C$ sources to the $\mathrm{PE}$ would be greater in macro-versus microaggregates. This hypothesis is because macroaggregates have more easily decomposable C (e.g., recent C) (Elliott, 1986; Six et al., 2002; Denef et al., 2007) and microorganisms will preferentially utilize labile substrate (Paterson et al., 2007; Kuzyakov, 2010), but the extent may depend on the primer amount. To test these hypotheses, we combined the recently developed isotopic approach for three-C-source-partitioning (substrate added, recent and old SOM) with fractionation of aggregate size classes and measured three fluxes and pools: $\mathrm{CO}_{2}$, microbial biomass $\mathrm{C}(\mathrm{MBC})$ and dissolved organic C (DOC).

\section{Materials and methods}

\subsection{Soil sampling and aggregate preparation}

Soil (loamy Haplic Luvisol originated from loess) was sampled in April 2012 from the upper layer $(0-10 \mathrm{~cm})$ of a maize field as well as from an adjacent wheat field located northwest of Göttingen, Germany. The soil had $5.8 \%$ sand, $87.2 \%$ silt and $7.0 \%$ clay according to the German classification system. The $\mathrm{C}_{4}$ plant maize (Zea mays) was grown for three years after long-term $C_{3}$ cropping with wheat (Triticum aestivum). The experimental design was described in detail by Kramer et al. (2012) and Pausch and Kuzyakov (2012).

The soil samples were transported to the laboratory, where plant roots and leaves were carefully removed by hand picking, and the soil samples were then stored at $4{ }^{\circ} \mathrm{C}$ for no longer than one week before aggregate processing. The soil was sieved to separate large macroaggregates $(>2 \mathrm{~mm})$, small macroaggregates $(2-0.25 \mathrm{~mm})$ and microaggregates $(<0.25 \mathrm{~mm})$ according to Tian et al. (2015). Soil was first gently manually crumbled to approximately $5 \mathrm{~mm}$ pieces, transferred to two sieves ( 2 and $0.25 \mathrm{~mm}$ ), and shaken for $2 \mathrm{~min}$. Thereafter, the aggregates remaining on top of the sieves were collected. Large macroaggregates were collected from the $2 \mathrm{~mm}$ sieve, small macroaggregates from the $0.25 \mathrm{~mm}$ sieve, and microaggregates that passed through the $0.25 \mathrm{~mm}$ sieve. The soil aggregates were then spread out in a thin layer and air-dried. Preliminary tests showed that the sieving duration was sufficient to separate the various aggregates size classes while minimizing aggregate abrasion during the sieving process (Dorodnikov et al., 2009).

The vegetation change from $C_{3}$ to $C_{4}$ crops caused a shift in the $\delta^{13} \mathrm{C}$ values of soil and of the aggregates (Table 1 ). Hence, through the vegetation change from $C_{3}$ to $C_{4}$ crops, a distinct isotopic signal was introduced into the soil that allowed for partitioning of old SOM $\left(C_{3}-C\right)$ and recent SOM $\left(C_{4}-C\right)$. Hereafter, $C_{4}$-derived $C$ is referred to as "recent" $\mathrm{C}$ ( $<3$ years), and $\mathrm{C}_{3}$-derived $\mathrm{C}$, which entered the soil before maize cropping, is referred to as "old" C ( $>3$ years).

Table 1

SOC and $\delta^{13} \mathrm{C}$ content in aggregate size classes in the reference and maize soils.

\begin{tabular}{lllll}
\hline Soil type & Aggregate size classes & $\mathrm{SOC}\left(\mathrm{g} \mathrm{kg}^{-1}\right)$ & $\mathrm{TN}\left(\mathrm{g} \mathrm{kg}^{-1}\right)$ & $\delta^{13} \mathrm{C}[\% 0]$ \\
\hline $\mathrm{C}_{3}$ reference soil & $>2 \mathrm{~mm}$ & 13.0 & 1.29 & -26.45 \\
& $2-0.25 \mathrm{~mm}$ & 13.6 & 1.39 & -26.51 \\
& $<0.25 \mathrm{~mm}$ & 12.4 & 1.27 & -26.34 \\
$\mathrm{C}_{3}-\mathrm{C}_{4}$ soil & $>2 \mathrm{~mm}$ & 12.3 & 1.26 & -23.81 \\
& $2-0.25 \mathrm{~mm}$ & 13.7 & 1.30 & -23.87 \\
& $<0.25 \mathrm{~mm}$ & 11.5 & 1.20 & -23.20 \\
\hline
\end{tabular}




\subsection{Incubation and sampling}

Soil samples (20 g dry weight) of each aggregate size class from both maize $\left(\mathrm{C}_{3}\right.$ MACROBUTTON InsGlyph e $\left.\mathrm{C}_{4}\right)$ and wheat $\left(\mathrm{C}_{3}\right)$ plots were placed in a thin and loose layer on the bottom of $250 \mathrm{ml}$ jars. The moisture content was adjusted to $50 \%$ of the water holding capacity (WHC), and the soil was then pre-incubated at $22{ }^{\circ} \mathrm{C}$ for one week because sieving affects the availability of SOM for microorganisms (Hartley et al., 2007) and may cause a temporal respiration flush (Blagodatskaya and Anderson, 1999). The following levels of glucose were added: 1 ) without glucose (control, addition of water only), 2) low glucose (GL, corresponding to $20.4 \mu \mathrm{g} \mathrm{C} \mathrm{g}^{-1}$ soil), and 3) high glucose ( $\mathrm{GH}$, corresponding to $204 \mu \mathrm{g} \mathrm{C} \mathrm{g}^{-1}$ soil). The added glucose was prepared from unlabeled glucose mixed with uniformly labeled ${ }^{14} \mathrm{C}$-glucose (99 $530 \mathrm{DPM}$ per jar) and water ( $\mathrm{GO})$. The appropriate glucose solutions were then added to the pre-incubated soils, which reached a final soil moisture content of $70 \%$ WHC. The water content was maintained at $70 \%$ WHC throughout the experiment. In total, a $3 \times 3 \times 2$ factorial experiment was established corresponding to three levels of aggregate sizes, three levels of glucose addition and two soils. Each treatment had three replicates. The C content was $12.3 \mathrm{~g} \mathrm{~kg}^{-1}$ in the $>2 \mathrm{~mm}$ aggregate size, $13.7 \mathrm{~g} \mathrm{~kg}^{-1}$ in the $2-0.25 \mathrm{~mm}$ aggregates size and $11.5 \mathrm{~g} \mathrm{~kg}^{-1}$ in the $<0.25 \mathrm{~mm}$ aggregates size before incubation (Table 1 ).

Small vials with $3 \mathrm{ml}$ of $1 \mathrm{M} \mathrm{NaOH}$ were placed in the incubation jars to trap $\mathrm{CO}_{2}$ after adding distilled water (control treatment) or the glucose solution (GL and GH treatments) to the soil. The jars were immediately sealed air-tight and were incubated for 49 days at $22{ }^{\circ} \mathrm{C}$ and at $70 \% \mathrm{WHC}$. The $\mathrm{NaOH}$ solution was exchanged $6 \mathrm{~h}, 1$, $3,7,14,21,36$ and 49 days after glucose addition. Each time after changing the $\mathrm{NaOH}$ solution, the incubation jars were kept open for 30 min to maintain an adequate $\mathrm{O}_{2}$ level. In addition, three incubation jars containing only $\mathrm{NaOH}$ were used as blanks to correct for the $\mathrm{CO}_{2}$ trapped from the air inside the vessels. Another three vials of $\mathrm{NaOH}$ for each treatment were used for sampling ${ }^{13} \mathrm{CO}_{2}$ at 3,14 and 49 days of incubation. Three replicates of each treatment were destructively sampled at days 3,14 and 49 to analyze the microbial biomass $C$ and dissolved organic $C$ and their $\delta^{13} \mathrm{C}$ signatures.

\subsection{Chemical analyses}

The amount of trapped $\mathrm{CO}_{2}$ was determined by the titration of $1 \mathrm{ml}$ of the $\mathrm{NaOH}$ solution with $0.1 \mathrm{M} \mathrm{HCl}$ against phenolphthalein after adding $1 \mathrm{ml}$ of $0.5 \mathrm{M} \mathrm{BaCl}_{2}$ solution. Another $1 \mathrm{ml}$ of the $\mathrm{NaOH}$ solution was added to $6 \mathrm{ml}$ Rothiscint scintillation cocktail (Roth Company, Germany) and was well mixed by vortexing. After the decay of chemiluminescence (after $24 \mathrm{~h}$ ), the ${ }^{14} \mathrm{C}$ activity was determined by a liquid scintillation counter (LS6500 Multi-Purpose Scintillation Counter, 217 Beckman, USA). The ${ }^{14} \mathrm{C}$ counting efficiency was approximately $92 \%$ and the ${ }^{14} \mathrm{C}$ activity measurement error did not exceed $2 \%$. To determine the $\delta^{13} \mathrm{C}$ values of $\mathrm{CO}_{2}$ trapped in $\mathrm{NaOH}$, the solution was first precipitated with $4 \mathrm{ml}$ of $0.5 \mathrm{M} \mathrm{SrCl}_{2}$ aqueous solution and then centrifuged four times at

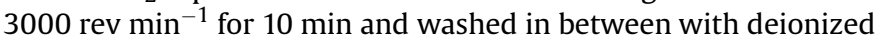
and degassed water to remove $\mathrm{NaOH}$ and to reach a $\mathrm{pH}$ of approximately 7 (Blagodatskaya et al., 2011). After washing, the $\mathrm{SrCO}_{3}$ was dried and analyzed for $\delta^{13} \mathrm{C}$ values on the IRMS (Delta plus, Finnigan MAT, Bremen, Germany).

The soil MBC was determined by chloroform fumigation extraction. The procedure (Wu et al., 1990; Vance et al., 1987) was adapted according to Malik et al. (2013). The non-fumigated and fumigated soil extracts were passed through a $0.45-\mu \mathrm{m}$ membrane filter and the dissolved organic $\mathrm{C}$ concentration of the extracts was measured with a TOC/TIC analyzer (Dimatec, Essen, Germany). Microbial biomass $C$ was calculated as the difference between the $C$ content of the fumigated and non-fumigated soil and divided by a $\mathrm{k}_{\mathrm{EC}}$ factor of 0.45 . The extract from the non-fumigated soil was used as a measure of the DOC. The ${ }^{14} \mathrm{C}$ activities of MBC and DOC were measured in $3 \mathrm{ml}$ aliquots added to $6 \mathrm{ml}$ Rothiscint scintillation cocktail (Roth Company, Germany) after the decay of chemiluminescence using a liquid scintillation counter (see above). Fumigated and non-fumigated extracts were dried at $60{ }^{\circ} \mathrm{C}$ and were analyzed for $\delta^{13} \mathrm{C}$ values on the IRMS (Delta plus, Finnigan MAT, Bremen, Germany).

\subsection{Calculations and statistics}

The $\delta^{13} \mathrm{C}$ values of total $\mathrm{MBC}\left(\delta^{13} \mathrm{C}_{\mathrm{MB}}\right)$ were determined using a mass balance equation:

$\delta^{13} C_{M B}=\left(\delta^{13} C_{f} \times C_{f}-\delta^{13} C_{n f} \times C_{n f}\right)\left(C_{f}-C_{n f}\right)$

where $\delta^{13} C_{\mathrm{f}}$ and $\delta^{13} \mathrm{C}_{\mathrm{nf}}$ are the $\delta^{13} \mathrm{C}$ values of the fumigated and non-fumigated samples, respectively, and $C_{f}$ and $C_{n f}$ are the amounts of $\mathrm{C}$ in the fumigated and non-fumigated samples, respectively.

We separated three sources of $\mathrm{C}$ in $\mathrm{CO}_{2}, \mathrm{MBC}$ and $\mathrm{DOC}$ following the detailed method of Blagodatskaya et al. (2011).

First, the glucose-derived $C$ in each pool $\left(C_{G \text {-derived }}\right)$ was calculated according to the specific ${ }^{14} \mathrm{C}$ activity of the added glucose $\left({ }^{14} C_{\text {glucose}}\right.$; DPM), the amount of added glucose $\left(C_{\text {glucose }}\right)$ and the current ${ }^{14} \mathrm{C}$ radioactivity of the corresponding pool $\left({ }^{14} \mathrm{C}_{\text {curr }}\right.$; DPM):

$\mathrm{C}_{\mathrm{G} \text {-derived }}=\mathrm{C}_{\text {glucose }} \times{ }^{14} \mathrm{C}_{\text {curr }} /{ }^{14} \mathrm{C}_{\text {glucose }}$

The SOM-derived C was then calculated as follows:

$\mathrm{C}_{\text {SOM-derived }}=\mathrm{C}_{\text {total }}-\mathrm{C}_{\mathrm{G} \text {-derived }}$

where $\mathrm{C}_{\text {total }}$ is the total amount of $\mathrm{C}$ in the corresponding pool $\left(\mathrm{CO}_{2}\right.$, $\mathrm{MBC}$ and $\mathrm{DOC}$ ).

Second, we calculated the $\delta^{13} \mathrm{C}$ value of SOM-derived $\mathrm{C}$ in each pool $\left(\delta^{13} C_{\text {SOM-derived }}\right)$ based on a mass balance equation. Therefore, the $\delta^{13} \mathrm{C}$ signature of glucose-derived $\mathrm{C}$ was subtracted from the $\delta^{13} \mathrm{C}$ signature of each pool:

$$
\begin{aligned}
\delta^{13} \mathrm{C}_{\text {SOM-derived }}= & \left(\delta^{13} \mathrm{C}_{\text {total }} \times \mathrm{C}_{\text {total }}-\delta^{13} \mathrm{C}_{\mathrm{G} \text {-derived }} \times \mathrm{C}_{\mathrm{G} \text {-derived }}\right) / \\
& \left(\mathrm{C}_{\text {total }}-\mathrm{C}_{\mathrm{G} \text {-derived }}\right)
\end{aligned}
$$

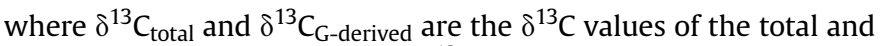
glucose-derived $C$, respectively. $\delta^{13} C_{\text {total }}$ are the measured values of the corresponding pool $\left(\mathrm{CO}_{2}, \mathrm{MBC}\right.$ and DOC). The $\delta^{13} \mathrm{C}_{\mathrm{G} \text {-derived was }}$ assumed to be equal to $\delta^{13} \mathrm{C}$ of glucose $(-9.905 \%)$.

The contribution of recent $C$ and old $C$ to each pool of the $C_{3}-C_{4}$ soil was then calculated based on the glucose-corrected $\delta^{13} \mathrm{C}$ signature of each pool. The amount of recent $\mathrm{C}_{4}$-derived $\mathrm{C}$ in each pool was:

$$
\begin{aligned}
\mathrm{C}_{\text {C4-derived }}= & \mathrm{C}_{\text {SOM-derived }} \times\left(\delta^{13} \mathrm{C}_{\text {SOM-derived }}-\delta^{13} \mathrm{C}_{\mathrm{C} 3 \text {-ref }}\right) / \\
& \left(\delta^{13} \mathrm{C}_{\mathrm{C} 4}-\delta^{13} \mathrm{C}_{\mathrm{C} 3}\right)
\end{aligned}
$$

where $\delta^{13} \mathrm{C}_{\mathrm{C} 3-r e f}$ is the $\delta^{13} \mathrm{C}$ value of the corresponding pool in the reference $C_{3}$ soil at the corresponding sampling data calculated according to Eq. (3).

The $\mathrm{C}_{4}$ source $\left(\delta^{13} \mathrm{C}_{\mathrm{C}}\right)$, i.e., soil $\mathrm{CO}_{2}, \mathrm{MBC}$ and $\mathrm{DOC}$, developed under permanent $C_{4}$ vegetation, was calculated based on the assumption of an equal isotopic fractionation within permanent $\mathrm{C}_{4}$ 
and $C_{3}$ systems (Werth and Kuzyakov, 2010). The isotopic fractionation factor for the $C_{3}$ system was:

$\mathrm{F}_{\mathrm{SOM}}=\delta^{13} \mathrm{C}_{\mathrm{C} 3 \text {-plant }}-\delta^{13} \mathrm{C}_{\mathrm{C} 3}$

$\delta^{13} \mathrm{C}_{\mathrm{C} 4}=\delta^{13} \mathrm{C}_{\mathrm{C} 4 \text {-plant }}-\mathrm{F}_{\mathrm{SOM}}$

where $\delta^{13} \mathrm{C}_{\mathrm{C} 3 \text {-plant }}$ was equal to $-27.893 \%$ and $\delta^{13} \mathrm{C}_{\mathrm{C} 4 \text {-plant }}$ was equal to $-12.221 \%$ in this study.

Third, the $\mathrm{C}_{\mathrm{C} 3 \text {-derived }}$ in each pool was then calculated by sub-

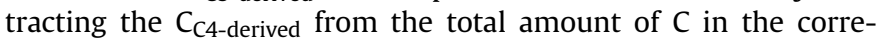
sponding pool.

Fourth, the PE and contributions of recent and old $\mathrm{C}$ to the PE were calculated based on the changes in the $\delta^{13} \mathrm{C}$ signature and the amount of extra $\mathrm{C}$ in the three pools after ${ }^{14} \mathrm{C}$-glucose addition.

The cumulative PE was calculated as the difference of SOMderived $\mathrm{C}$ (in $\mathrm{CO}_{2}, \mathrm{MBC}$ and $\mathrm{DOC}$ ) from soil with a glucose addition and from soil without a glucose addition (Blagodatskaya et al., 2007):

$\mathrm{PE}\left(\mu \mathrm{g} \mathrm{C} \mathrm{g}{ }^{-1}\right.$ soil $)=$ SOM-derived $\mathrm{C}_{\text {amended }}$-SOM-derived

$$
\mathrm{C}_{\text {unamended }}
$$

where SOM-derived $\mathrm{C}_{\mathrm{amended}}$ was SOM-derived $\mathrm{C}$ (in $\mathrm{CO}_{2}, \mathrm{MBC}$ and DOC) from the jar with glucose addition, and SOM-derived $C$ was from the jar without glucose addition.

The changes in the $\delta^{13} \mathrm{C}$ signature caused by preferential substrate utilization of easily available and ${ }^{13} \mathrm{C}$-enriched recent $\mathrm{C}$ (compared with ${ }^{13} \mathrm{C}$ depleted old $\mathrm{C}$ ), were considered for the correct assessment of PE in all pools (Connin et al., 2001; Crow et al., 2006; Blagodatskaya et al., 2011; Ngao and Cotrufo, 2011). The dynamic changes in $\delta^{13} \mathrm{C}$ caused by preferential utilization were estimated in control $\mathrm{C}_{3}-\mathrm{C}_{4}$ soil treated solely with $\mathrm{H}_{2} \mathrm{O}$. Therefore, for each pool $\left(\mathrm{CO}_{2}, \mathrm{MBC}\right.$ and $\left.\mathrm{DOC}\right)$, the PE was calculated separately for $\mathrm{C}_{3}$ and $\mathrm{C}_{4}$ carbon sources ( $C_{3} \_P E$ and $C_{4} \_P E$, respectively) considering the changes in the contribution of old and recent $\mathrm{C}$ in controls for each sampling data:

$$
\begin{aligned}
& C_{3 \_} P E=C_{3 \_C}^{\text {amended }}-C_{3 \_}^{\text {unamended }} \\
& C_{4} \text { PE }=C_{4}^{\text {amended } C}-C_{4} \text { unamended }
\end{aligned}
$$

The data were analyzed using a two-way or three-way analysis of variance (ANOVA) with SAS (SAS Inc. 1996). Differences were considered significant at $p<0.05$, with a separation of mean values by a least significant difference (LSD) test.
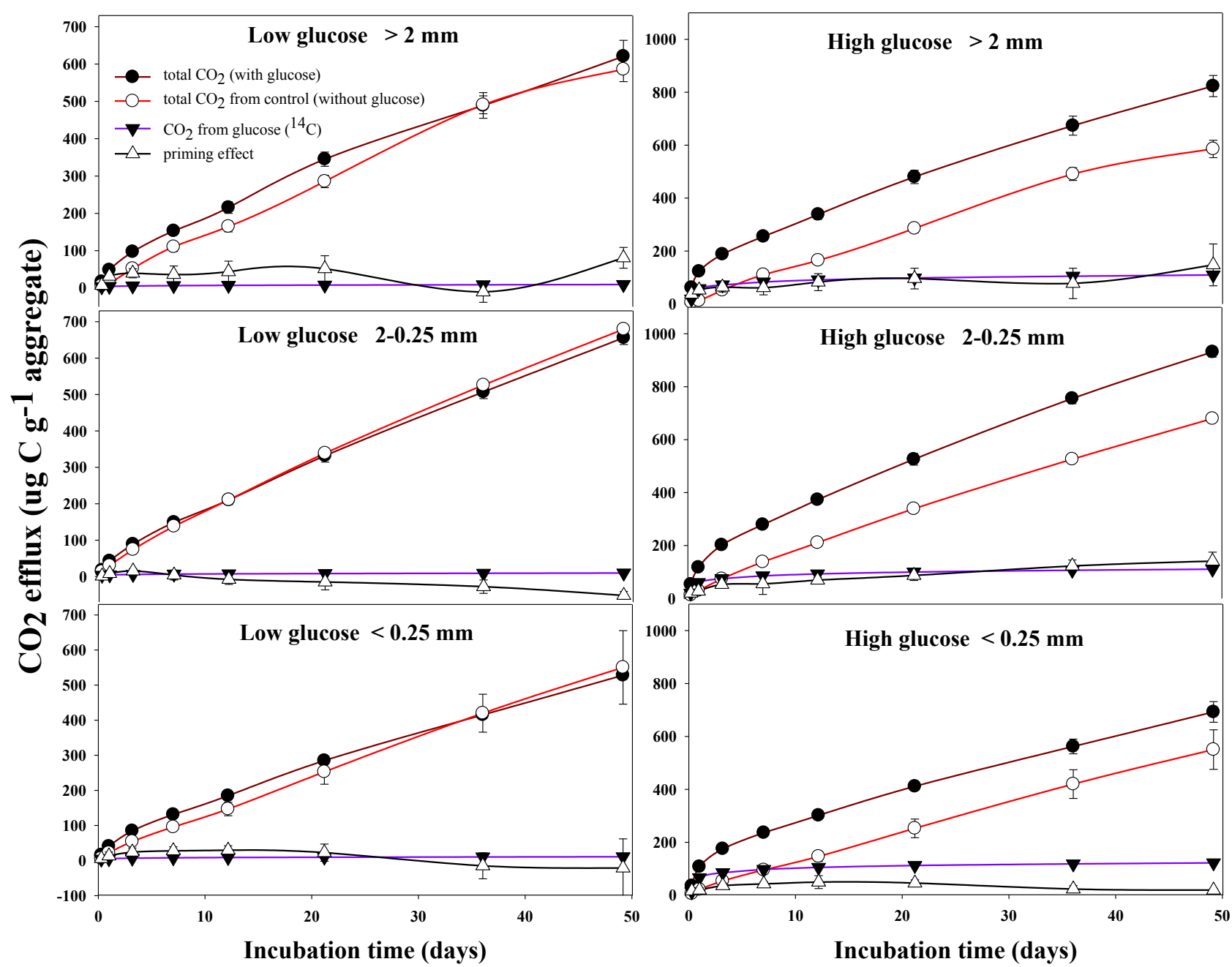

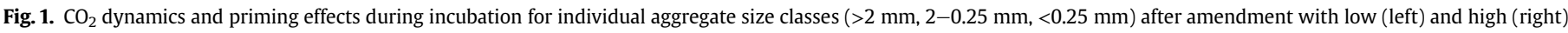
glucose levels in $C_{3}-C_{4}$ soil. Error bars represent standard error of the means $(n=3)$. 


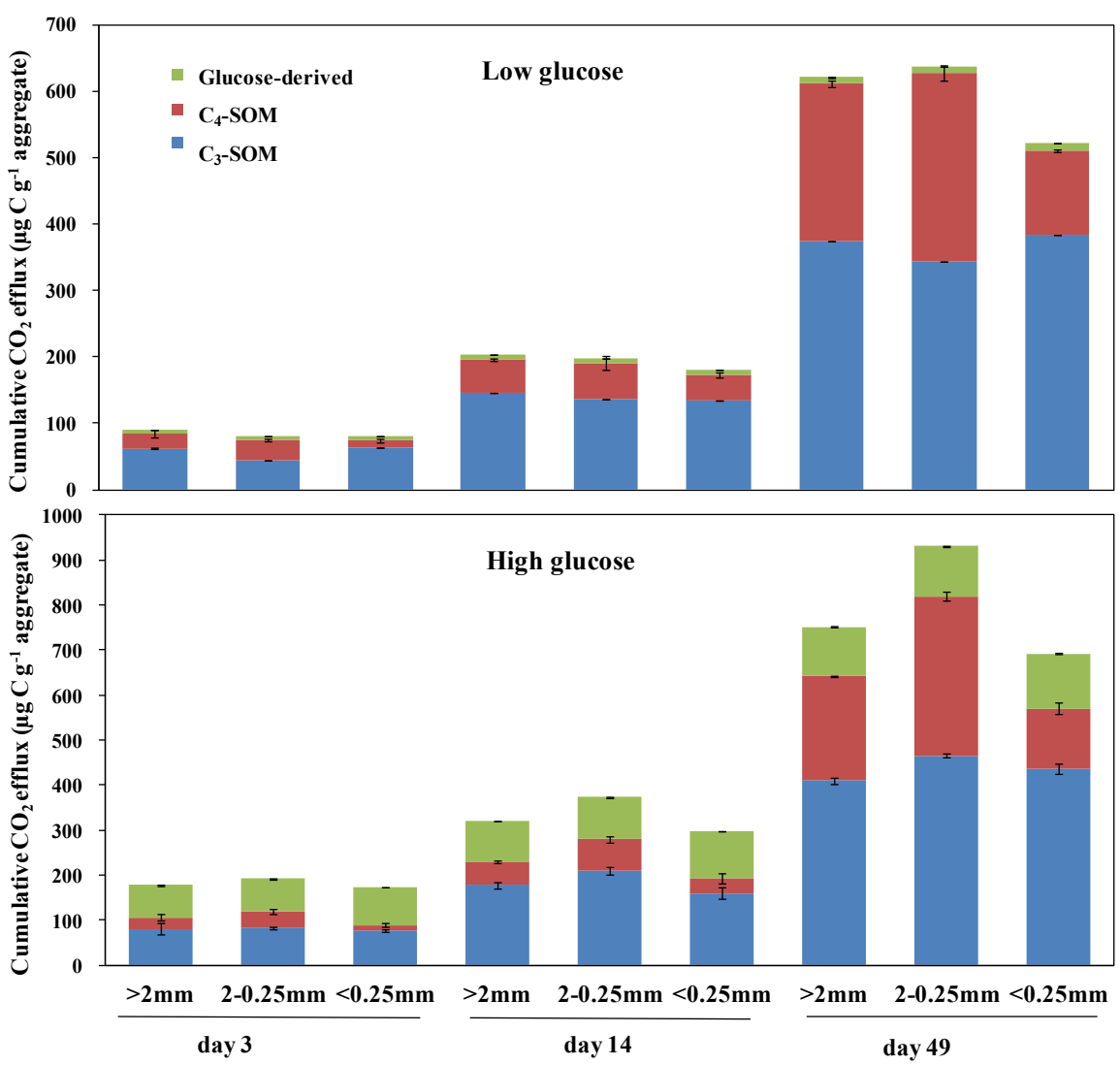

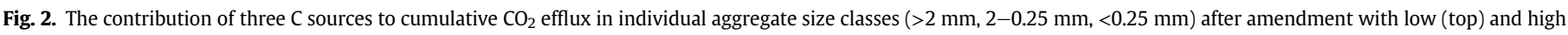
(bottom) glucose levels. Error bars represent standard error of the means $(n=3)$.

\section{Results}

3.1. Sources partitioning for C pools in aggregate size classes depending on glucose levels

\subsection{1. $\mathrm{CO}_{2}$ efflux}

The total $\mathrm{CO}_{2}$ efflux during the intensive decomposition stage (the first 3 days) was mainly affected by the level of glucose addition (accounting for $96 \%$ variance; $p<0.05$; Fig. 1 and Table S1). In contrast, the effect of aggregate size classes on total $\mathrm{CO}_{2}$ production increased over 49 days compared with the first 3 days $(p<0.05$; Fig. 1 and Table S1).

$\mathrm{CO}_{2}$ originating from glucose increased with the glucose addition rate but decreased with time $(p<0.05$; Fig. 2; Table S2). The glucose-derived $\mathrm{CO}_{2}$ production was $26 \%$ higher for the $\mathrm{GH}$ treatment than for the GL treatment after day 3, while it was $14 \%$ higher after day 49 ( $p<0.05$; Fig. 1 ; Table 2; Table S1 and S2). The glucosederived $\mathrm{CO}_{2}$ increased with decreasing aggregate size classes $\left(p<0.05\right.$; Fig. 2; Table S2). Glucose-derived $\mathrm{CO}_{2}$ production after 3 days was $16.4 \%$ higher in the microaggregates $(<0.25 \mathrm{~mm})$ than in the macroaggregates $(>0.25 \mathrm{~mm})$, while it was $11.5 \%$ higher after day 49 ( $p<0.05$; Fig. 1 ; Table 2; Table $\mathrm{S} 1$ ).

The $\mathrm{CO}_{2}$ originating from recent $\mathrm{C}_{4}-\mathrm{C}$ was affected by aggregate size classes, while $\mathrm{CO}_{2}$ originating from old $\mathrm{C}_{3}-\mathrm{C}$ was influenced by glucose levels $\left(p<0.05\right.$; Fig. 2; Table $\mathrm{S} 2$ ). The $\mathrm{CO}_{2}$ originating from recent $C_{4}-C$ and old $C_{3}-C$ were both influenced by the interactions between aggregate size classes and glucose levels $(p<0.05$; Table S2). The contribution of recent $\mathrm{C}_{4}-\mathrm{C}$ to $\mathrm{CO}_{2}$ was $45.7-58.7 \%$ higher in the macroaggregates $(>0.25 \mathrm{~mm})$ than in the microaggregates $(<0.25 \mathrm{~mm} ; p<0.05$; Fig. 2; Table s2). The contribution of old $\mathrm{C}_{3}-\mathrm{C}$ to $\mathrm{CO}_{2}$ was $10.3-31.1 \%$ higher under $\mathrm{GH}$ than $\mathrm{GL}$ levels $\left(p<0.05\right.$; Fig. 2; Table S2). The contribution of recent $C_{4}$-derived

Table 2

Production of glucose-derived $\mathrm{CO}_{2}, \mathrm{C}_{3}$-derived $\mathrm{CO}_{2}$ and $\mathrm{C}_{4}$-derived $\mathrm{CO}_{2}$ after 49 days across aggregate size classes and glucose amendment treatments.

\begin{tabular}{|c|c|c|c|c|c|}
\hline \multirow[t]{2}{*}{ Treatments } & Glucose-derived $\mathrm{CO}_{2}$ & $\mathrm{C}_{4}$-derived $\mathrm{CO}_{2}$ & $\mathrm{C}_{3}$-derived $\mathrm{CO}_{2}$ & $\mathrm{C}_{4}$-derived $\mathrm{CO}_{2}$ & $\mathrm{C}_{3}$-derived $\mathrm{CO}_{2}$ \\
\hline & \multicolumn{3}{|l|}{ ( $\mu \mathrm{g} \mathrm{C}^{-1}$ aggregate) } & \multicolumn{2}{|c|}{ (\% of SOC content in aggregate) } \\
\hline$>2 \mathrm{~mm}$ & $59.0(28.7) b$ & $234(2.71) b$ & $392(15.0)$ & $1.91(0.02) b$ & 3.19(0.12)ab \\
\hline $2-0.25 \mathrm{~mm}$ & $60.9(29.6) b$ & $319(22.5) a$ & $404(35.7)$ & $2.33(0.16) a$ & $2.95(0.26) b$ \\
\hline$<0.25 \mathrm{~mm}$ & 66.3(32.1)a & $128(2.70) \mathrm{c}$ & 397(15.7) & $1.12(0.02) \mathrm{c}$ & $3.45(0.14) a$ \\
\hline GL & $9.87(0.28) \mathrm{b}$ & $216(29.9)$ & 367(11.7)b & $1.70(0.19)$ & $2.96(0.17) \mathrm{b}$ \\
\hline GH & $114(2.52) \mathrm{a}$ & $239(41.2)$ & 429(13.7)a & $1.87(0.27)$ & $3.44(0.07) a$ \\
\hline
\end{tabular}

Numbers in bracket represent standard error of the means $(n=3)$.

GL: low glucose addition, GH: high glucose addition.

Different low-case letters indicate significant differences among across aggregate size classes or glucose amendment treatments. 

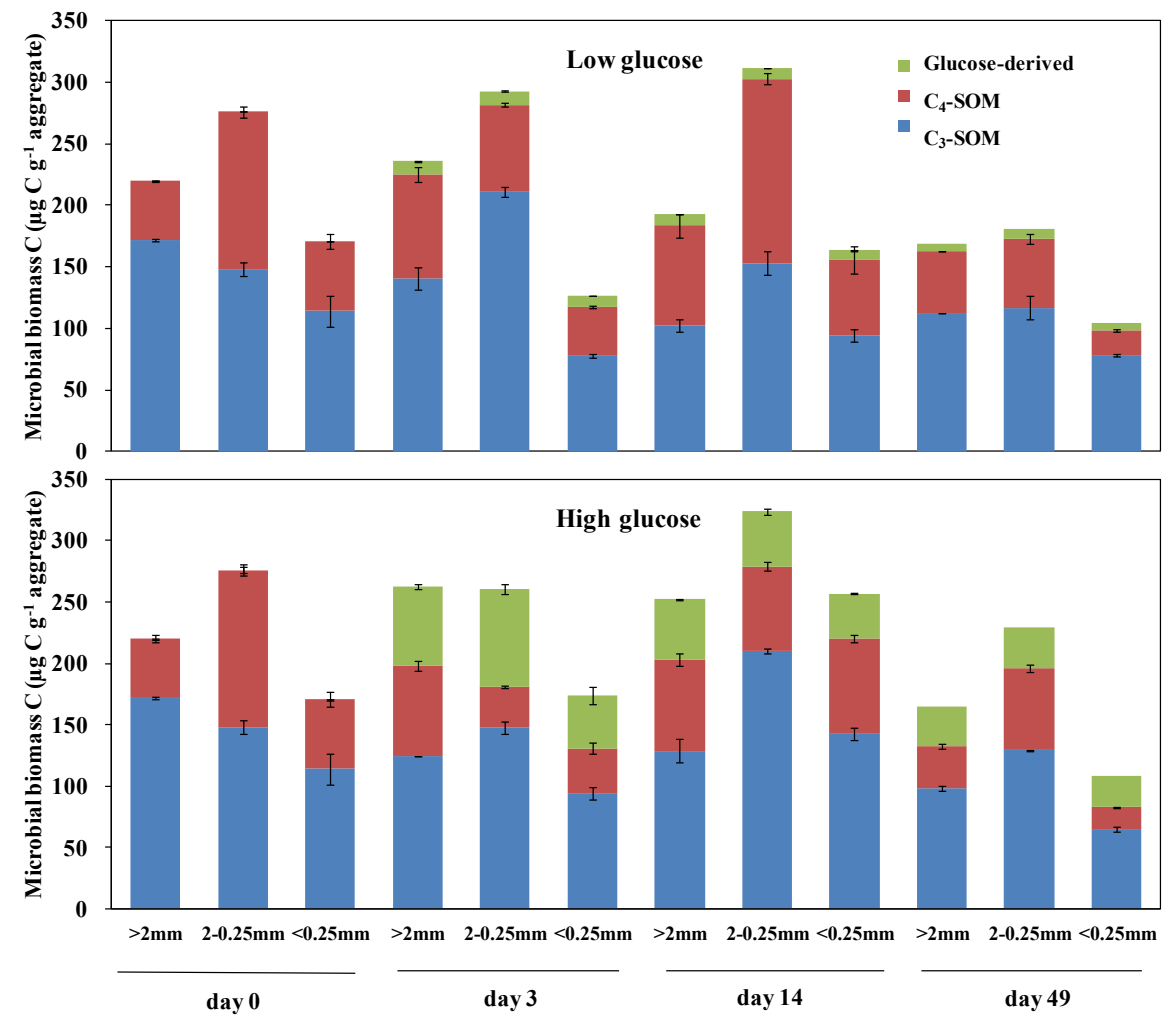

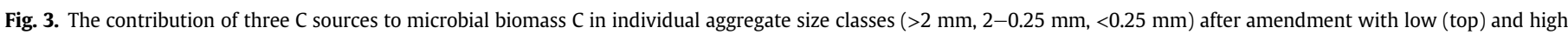
(bottom) glucose levels. Error bars represent standard error of the means $(n=3)$.

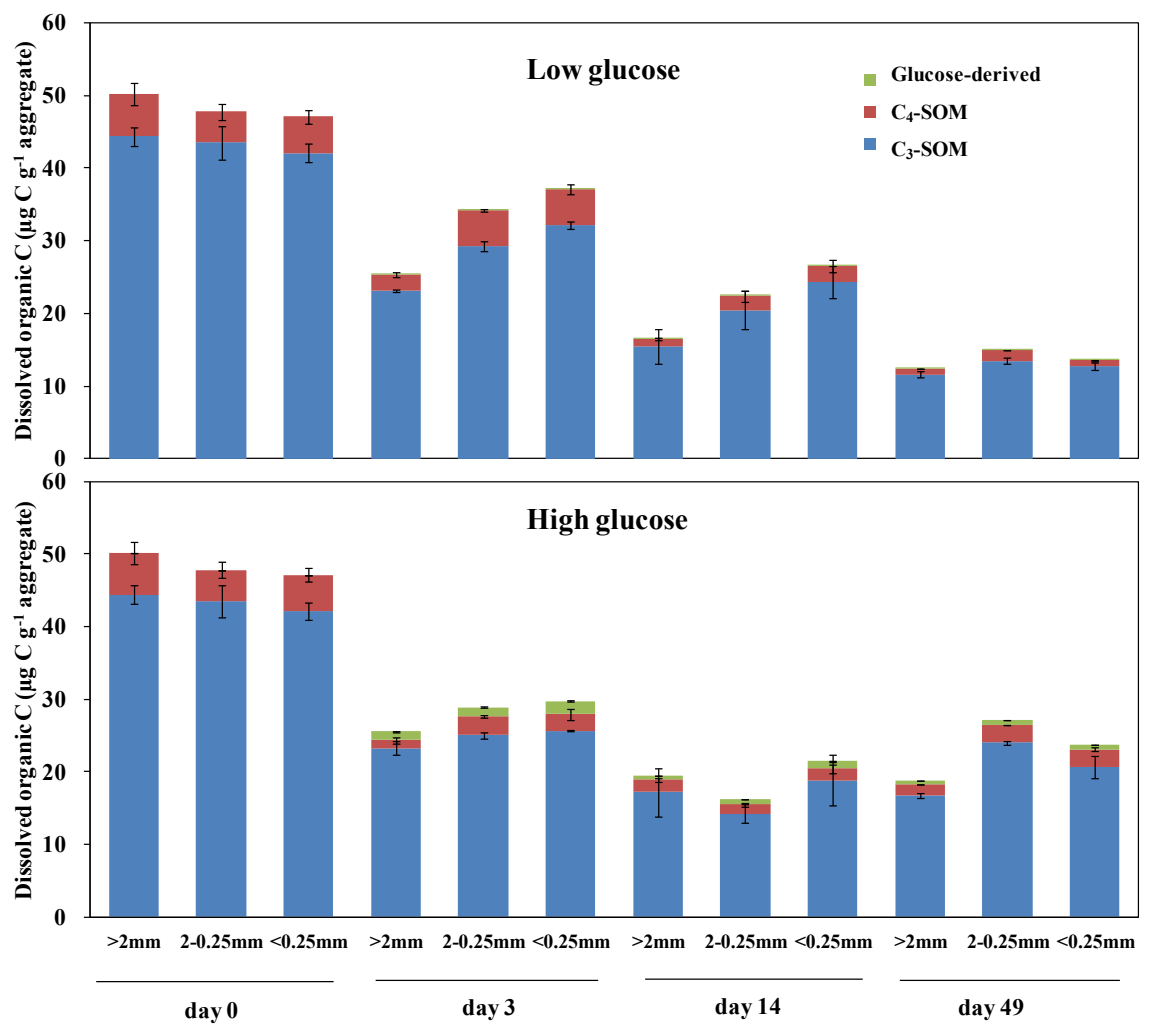

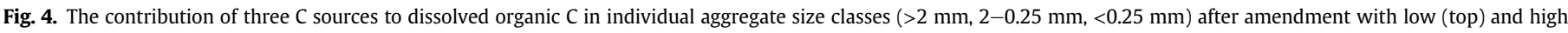
(bottom) glucose levels. Error bars represent standard error of the means $(n=3)$. 
$\mathrm{CO}_{2}$ and old $\mathrm{C}_{3}$-derived $\mathrm{CO}_{2}$ to $\mathrm{SOC}$ in aggregate size classes followed a similar trend as that to total $\mathrm{CO}_{2}$ (Table 2).

\subsubsection{Microbial biomass $C$}

The level of glucose addition explained most of the differences in glucose-derived microbial biomass $C$, accounting for $73.1 \%$ variation ( $p<0.05$; Table $\mathrm{S} 2$ ). The glucose-derived microbial biomass $\mathrm{C}$ was 5.3 times higher under GH than GL levels $(p<0.05$; Fig. 3; Table S2). When averaged across all glucose levels and sampling dates, glucose-derived microbial biomass $C$ was $29.9 \%$ higher in the macroaggregates $(>0.25 \mathrm{~mm})$ than in the microaggregates $(<0.25 \mathrm{~mm} ; p<0.05$; Fig. 3 ; Table S2).

The microbial biomass $C$ originated from old $C_{3}-C(66.3 \%)$ nearly doubled recent $\mathrm{C}_{4}-\mathrm{C}(33.7 \%)$ before adding glucose (Fig. 3 ). Adding glucose did not increase the microbial biomass after day 3 but resulted in a 13-17.3\% increase in the microbial biomass $C$ in the $2-0.25 \mathrm{~mm}$ aggregate size class after day 14 ( $p<0.05$; Fig. 3 ). This increase was mainly due to an increase in recent $C_{4}-C(16.8 \%)$ under GL, while old $\mathrm{C}_{3}-\mathrm{C}$ was increased under $\mathrm{GH}$ (42.7\%) (Fig. 3).

\subsubsection{Dissolved organic $C$}

Dissolved organic $\mathrm{C}$ originating from glucose was nearly tenfold higher under GH than GL treatments ( $p<0.05$; Fig. 4; Table S2). Glucose-derived ${ }^{14} \mathrm{C}$ in dissolved organic matter was $14.6 \%$ higher in the microaggregates $(<0.25 \mathrm{~mm})$ than in the macroaggregates $(>0.25 \mathrm{~mm})$ under $\mathrm{GL}$, while it was $28.4 \%$ higher under $\mathrm{GH}$ $(p<0.05$; Fig. 4; Table S2).

Initially, the dissolved organic $C$ pool consisted mainly of old
$C_{3}-C$ (89.4\%), while recent $C_{4}-C$ was only $19.6 \%$ (Fig. 4). The dissolved organic $C$ content after glucose amendment was always lower than before adding glucose ( $p<0.05$; Fig. 4$)$. For example, dissolved organic $C$ decreased almost 39.2\% during the first 3 days after glucose addition (Fig. 4). This decrease was due to $20.1 \%$ and $34.9 \%$ reduction of recent $C_{4}$ and old $C_{3}-C$, respectively, under $G L$, while the decrease was $60.9 \%$ and $43.1 \%$ under $\mathrm{GH}$, respectively (Fig. 4). The portion of recent $\mathrm{C}_{4}-\mathrm{C}$ in dissolved organic matter decreased by $69.0 \%$ after 49 days of incubation compared to day 0 , while old $\mathrm{C}_{3}-\mathrm{C}$ was decreased by $61.8 \%$.

\subsection{Sources of priming effects}

The cumulative $\mathrm{PE}$ in $\mathrm{CO}_{2}$ was mainly positive during the experiment for all treatments, except for the $2-0.25 \mathrm{~mm}$ and $<0.25 \mathrm{~mm}$ aggregate size classes with GL addition, where negative $\mathrm{PE}$ was detected (Figs. 1 and 5). The cumulative $\mathrm{PE}$ in $\mathrm{CO}_{2}$ increased with glucose levels ( $p<0.05$; Fig. 5, Table S3). The positive PE during the first 3 days originated mainly from the $C_{3}-C$. However, the portion of recent $\mathrm{C}_{4}-\mathrm{C}$ in cumulative PE increased during the course of further incubation, except the $2-0.25 \mathrm{~mm}$ and $<0.25 \mathrm{~mm}$ aggregate size classes with GL addition, where a negative PE was measured (Fig. 5).

The increase in microbial biomass after glucose addition after day 14 originated by $84.4-96.1 \%$ from SOC. This resulted in increased PE in MBC (Fig. 6). This increased PE was mainly due to old $\mathrm{C}_{3}-\mathrm{C}$ under $\mathrm{GH}$, while both recent $\mathrm{C}_{4}-\mathrm{C}$ and old $\mathrm{C}_{3}-\mathrm{C}$ contributed to PE under GL. At the end of incubation, the portion of

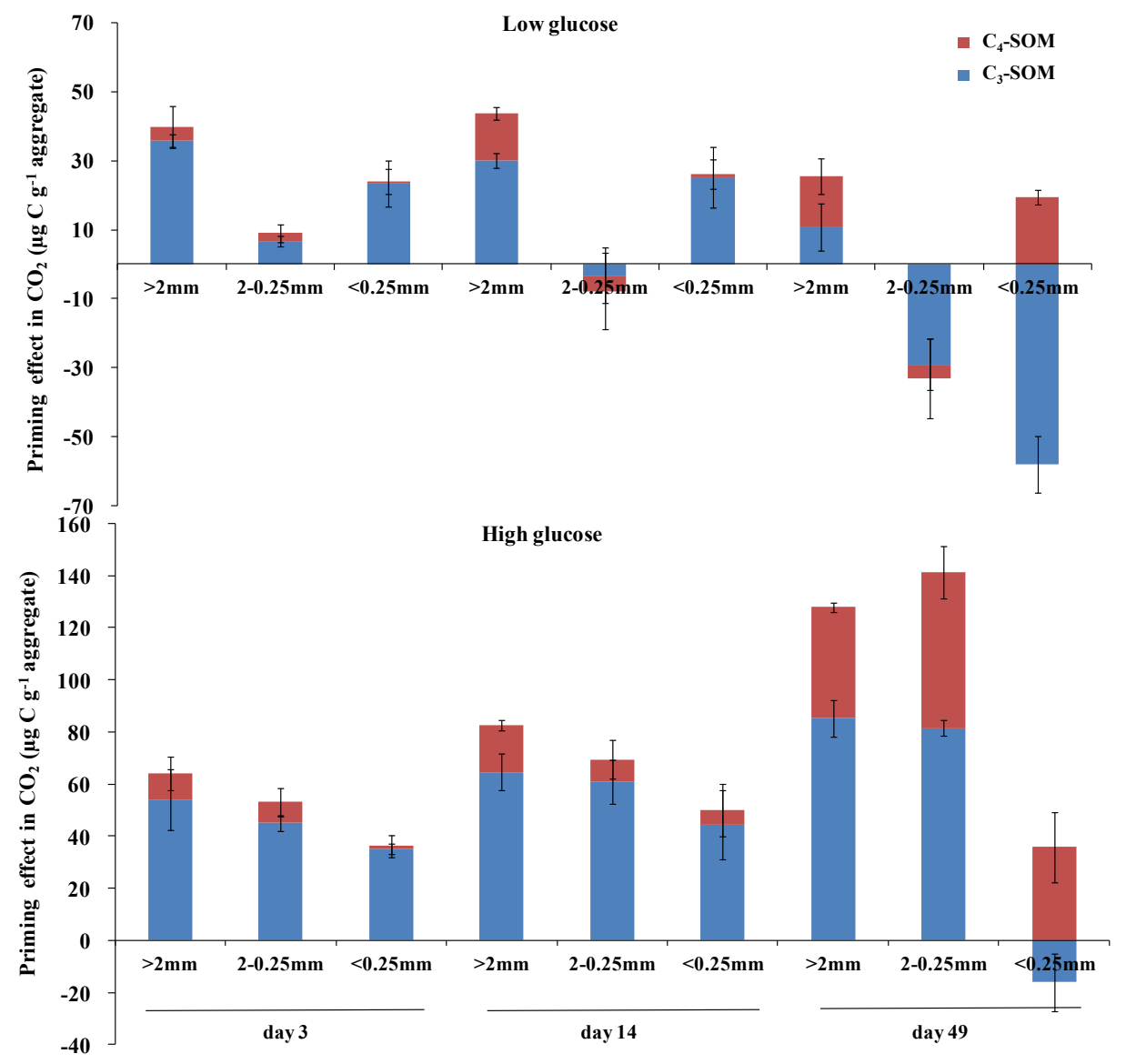

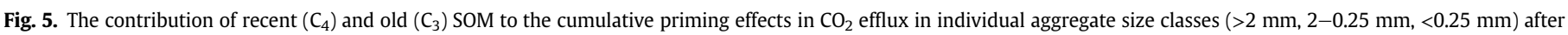
amendment with low (top) and high (bottom) glucose levels. Error bars represent standard error of the means $(\mathrm{n}=3)$. 
$\mathrm{C}_{4}-\mathrm{C}$ in $\mathrm{PE}$ of microbial biomass $\mathrm{C}$ was higher in the macroaggregates $(>0.25 \mathrm{~mm})$ than in the microaggregates $(<0.25 \mathrm{~mm})$ under both glucose levels ( $p<0.05$; Fig. 6; Table S3).

The reduction in DOC content after glucose addition resulted in positive PE (Fig. 7). The portions of $\mathrm{C}_{4}-\mathrm{C}$ and $\mathrm{C}_{3}-\mathrm{C}$ in PE of DOC were both influenced by aggregate size classes, incubation time and the interactions between them $(p<0.05$, Table S3). The portions of $\mathrm{C}_{4}-\mathrm{C}$ and $\mathrm{C}_{3}-\mathrm{C}$ in PE of DOC were both higher in the macroaggregates $(>0.25 \mathrm{~mm})$ than in the microaggregates $(<0.25 \mathrm{~mm})$ before day 14 ( $p<0.05$, Fig. 7 ; Table S3). The contribution of old $\mathrm{C}_{3}-\mathrm{C}$ in PE of DOC in all aggregates size classes decreased from day 3 to day 49 ( $p<0.05$, Fig. 7$)$.

\section{Discussion}

4.1. $\mathrm{CO}_{2}$ efflux as affected by aggregate size class and the amount of primer

The level of glucose had the greatest effect on the total and glucose-derived $\mathrm{CO}_{2}$ production during the intensive decomposition stage (before day 3, Table S1). This finding is in line with previous studies (Saggar et al., 1999; Ohm et al., 2007; Hill et al., 2008). Generally, high amounts of glucose can stimulate more microorganisms to grow and mineralize the "new" added $\mathrm{C}$ to $\mathrm{CO}_{2}$ (Schneckenberger et al., 2008). As microbial biomass did not increase after day 3 (Fig. 3), the higher proportion of mineralized ${ }^{14} \mathrm{C}$ glucose under high versus low glucose treatments may indicate decreased C use efficiency (CUE) (Creamer et al., 2014). Indeed, we found that the CUE was 1.4-2.0 times higher under low versus high glucose treatment in individual aggregates and across all aggregate size classes (Table S4), showing that CUE increased with rising C limitations (Nguyen and Guckert, 2001; Bremer and Kuikman, 1994).

The influence of aggregate size classes on total $\mathrm{CO}_{2}$ and glucosederived $\mathrm{CO}_{2}$ emission increased by a factor of 10 after 49 days compared with 3 days (Fig. 1 and Table S1), indicating that the starving microorganisms switched to utilization of SOM after the easily available glucose was consumed (Dungait et al., 2012). The observed increase in total $\mathrm{CO}_{2}$ in the macro-versus microaggregates can be explained by stronger protection of SOC within microaggregates (Elliott, 1986; Six et al., 2002; Denef et al., 2007; Kimura et al., 2012). This is inconsistent with a greater $\mathrm{CO}_{2}$ production observed from the smallest aggregates (Seech and Beauchamp, 1988; Drury et al., 2004; Sey et al., 2008) or with no difference between macro- and micro-aggregates (Rabbi et al., 2014). The observed inconsistency on the effects of aggregate sizes on mineralization may be due to differences in the organic $C$ content or the microbial community composition in various soils (Kimura et al., 2012). In addition, according to the aggregate hierarchy model, because microaggregates form inside macroaggregates (Six et al., 2000; Six and Paustian, 2014), the SOC mineralization in macroaggregates also includes $\mathrm{C}$ mineralization from the microaggregates that are embedded in them. Thus, macro- and microaggregates in the same soil could have similar chemically stable SOC, leading to no difference of mineralization between them (Rabbi et al., 2014).

The lower proportion of mineralized ${ }^{14} \mathrm{C}$-glucose, along with the higher proportion of added glucose incorporated into the microbial biomass in macro-versus microaggregates (Figs. 1 and 3), indicates greater CUE with increasing aggregate size. The higher

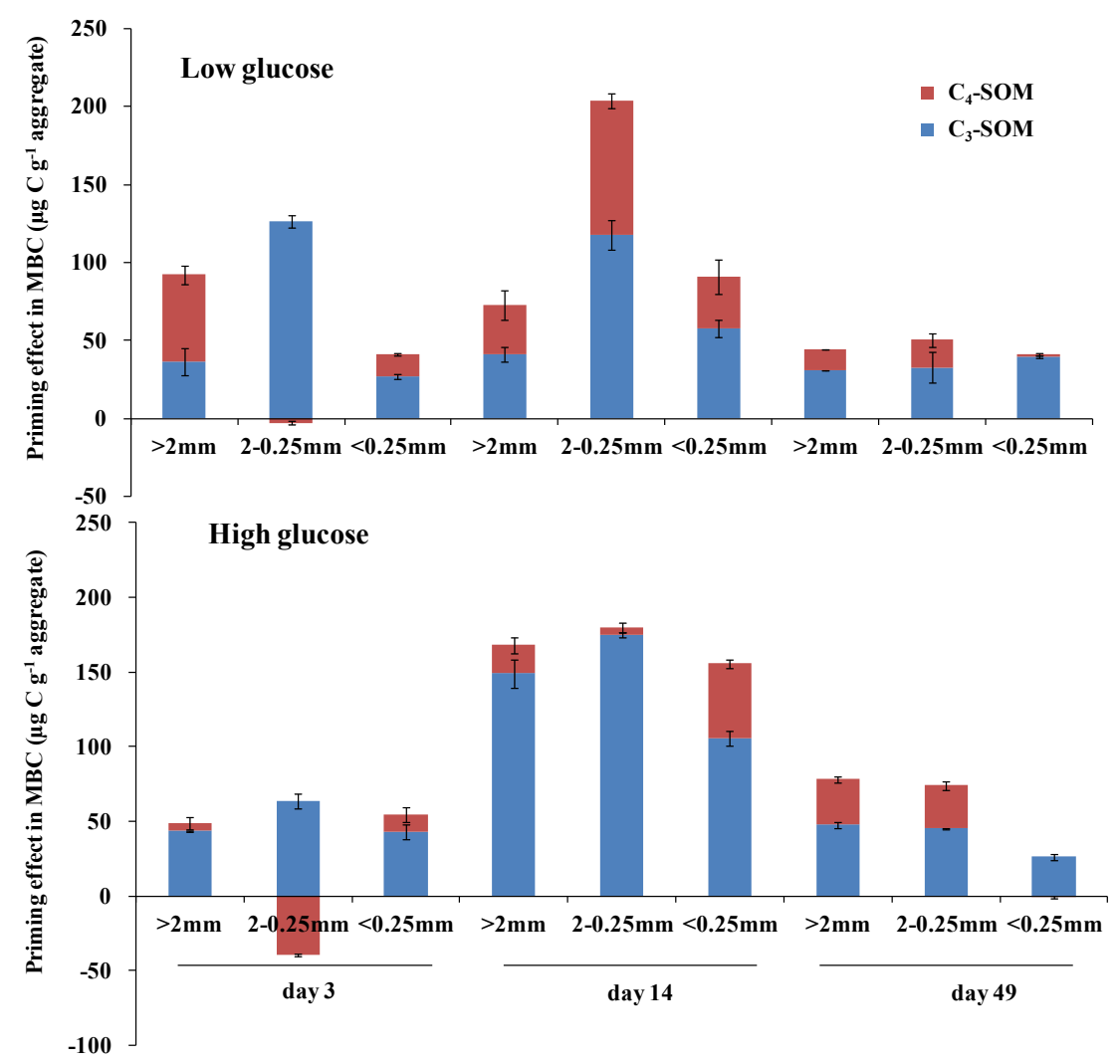

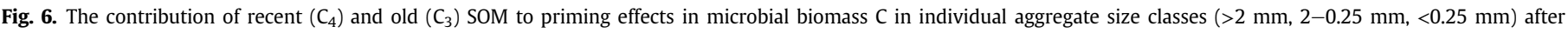
amendment with low (top) and high (bottom) glucose levels. Error bars represent standard error of the means $(n=3)$. 


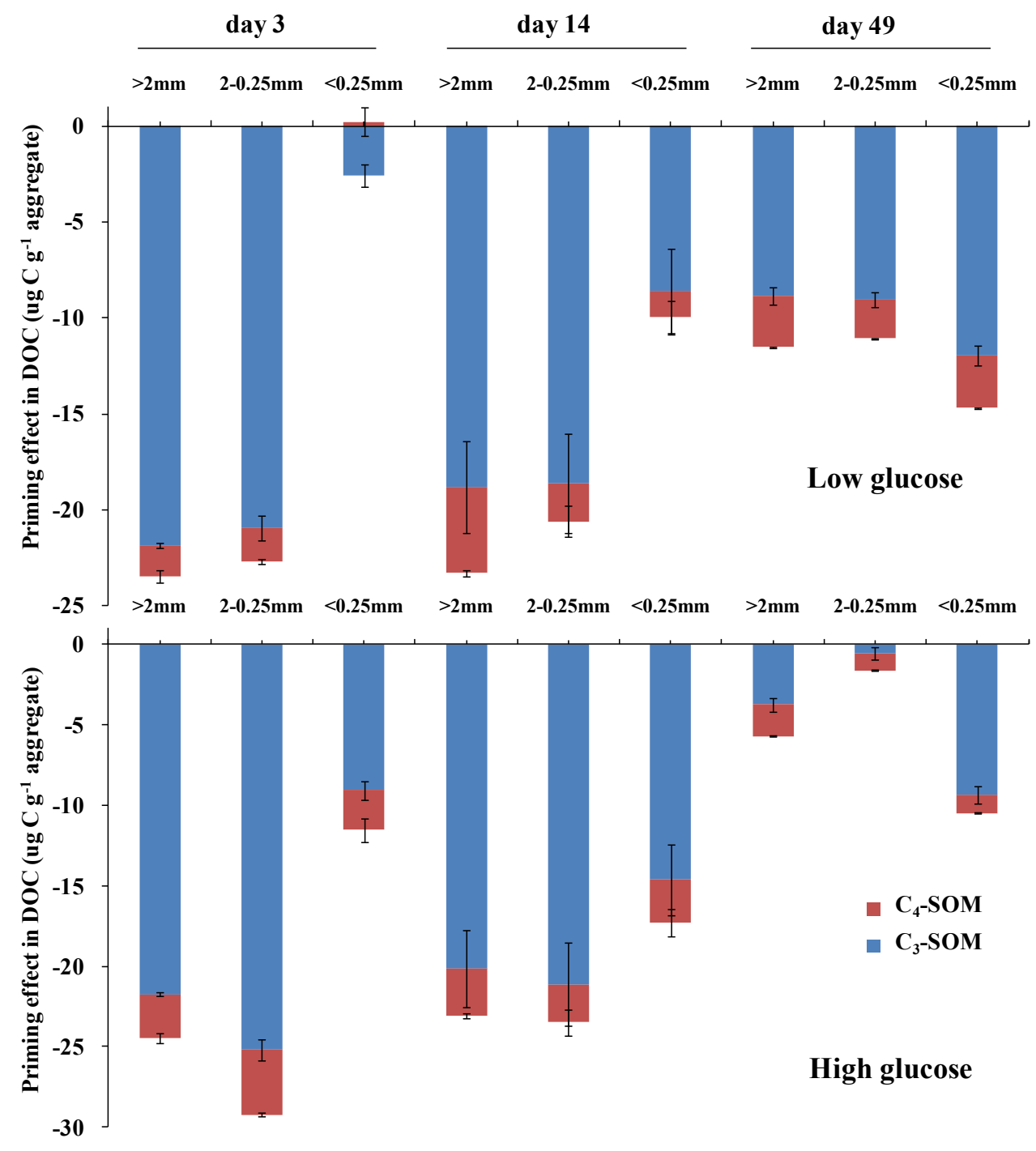

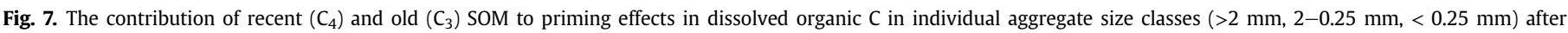
amendment with low (top) and high (bottom) glucose levels. Error bars represent standard error of the means $(n=3)$.

(22.1-84.9\%) CUE in macro-versus microaggregates may be explained by differences in the microbial community structures in various aggregate size classes. Generally, the fungal population utilizes the substrate more efficiently than bacteria (Otten et al., 2001; Keiblinger et al., 2010), while fungi occur mainly in macroaggregates (Guggenberger et al., 1999; Zhang et al., 2014). Differences in nutrient availability between macro- and microaggregates can also affect the CUE because soil organic materials can decompose more efficiently (i.e., less $\mathrm{CO}_{2}$ is emitted per unit of $\mathrm{C}$ incorporated in microbial biomass) in $\mathrm{N}$ and $\mathrm{P}$ amended soil ( $\mathrm{Li}$ et al., 2014). Macroaggregates usually represent an important site of nutrient (e.g., N, P) accumulation (Green et al., 2005; Fonte et al., 2014).

\subsection{Priming effect as affected by aggregate size class and primer amount}

The short-term positive PE in $\mathrm{CO}_{2}$ accompanied by a rapid DOC reduction (Figs. 4 and 5) is in line with the pattern observed after application of either easily available substrates (Blagodatskaya et al., 2011) or less available cellulose (Blagodatskaya et al., 2014). Despite glucose being incorporated within 3 days, microbial biomass only increased 14 days after glucose amendment (Fig. 3), reflecting faster microbial turnover. The microbial loop phenomenon, i.e., grazing of bacterial cells by protozoans in short-term soil amendment with substrate, may be another reason for the remaining constant level of microbial biomass (Clarholm, 1985; Coleman, 1994; Blagodatskaya et al., 2014). As the increase in SOM-derived microbial biomass and in primed $\mathrm{CO}_{2}$ induced by glucose was higher than the decline in SOM-derived DOC, the PE in $\mathrm{CO}_{2}$ originated not only from DOC but also from SOM. This also corresponds well with the finding that primed $\mathrm{CO}_{2}$ mainly originated from old $\mathrm{C}_{3}-\mathrm{C}$.

Positive PE was observed only in larger macroaggregates (>2 mm) over 49 days at a low glucose level (Fig. 8), thus supporting our first hypothesis that SOM pools are involved in PE according to their biochemical availability. This result indicates that SOM is less recalcitrant and more decomposable in macro-versus microaggregates (Elliott, 1986; Six et al., 2000; Denef et al., 2007; Gunina and Kuzyakov, 2014). Microaggregates are formed during 


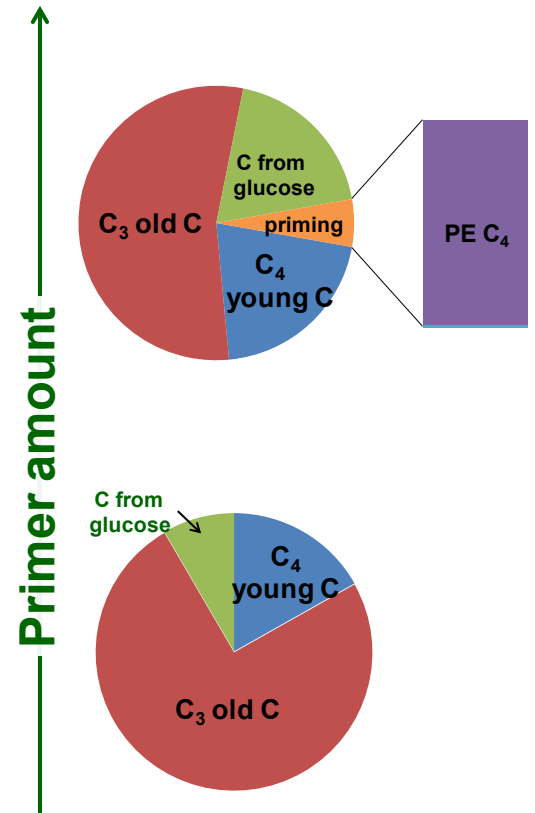

Microaggregates $(<0.25 \mathrm{~mm})$
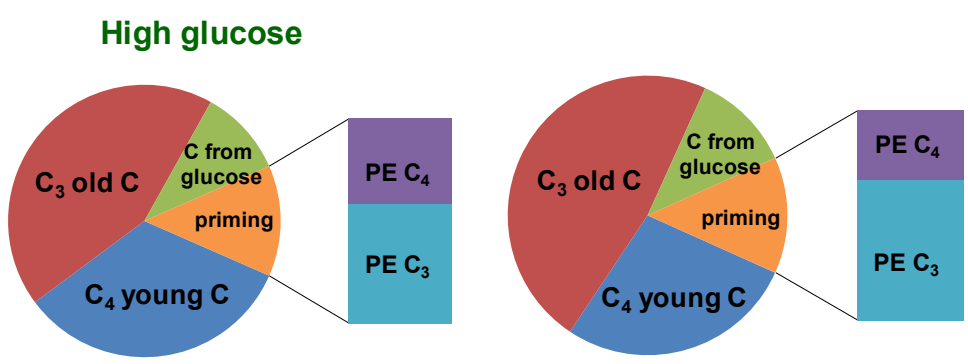

Low glucose

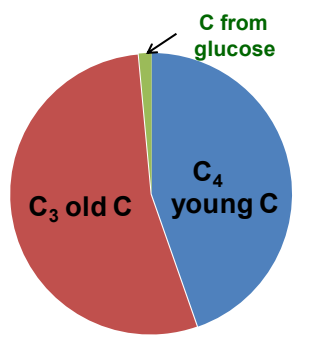

Macroaggregates $(2-0.25 \mathrm{~mm})$

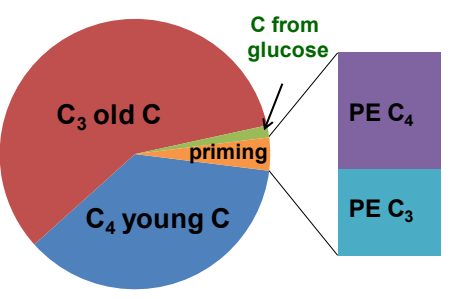

Macroaggregates (>2 $\mathrm{mm}$ )

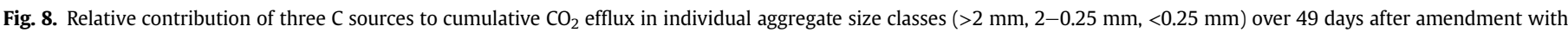

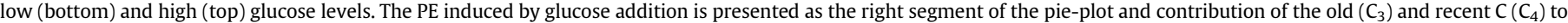
the primed $C$ is shown as stacked columns.

macroaggregates turnover, so they contained a relatively stable mixture of highly processed organic matter and secondary materials (Six et al., 2000; Six and Paustian, 2014). However, under high glucose amendment, positive PE was observed in all aggregate size classes but was lowest in microaggregates ( $<0.25 \mathrm{~mm}$; Fig. 8). This confirms our second hypothesis stating that the amount of primer was also responsible for PE. Therefore, old SOM mineralization can be fueled by a larger amount of energy-rich substrates due to stimulation of higher enzyme production to meet microbial nutrient demands or higher bacterial diversity (Paterson et al, 2007; Mau et al., 2015). This result agrees with studies showing that the SOM fractions with low degradability can be affected by PE after repeated substrate inputs (Hamer and Marschner, 2005; Fontaine et al., 2007; Mau et al., 2015) and high amounts of primer (Blagodatskaya et al., 2011). As the lowest positive PE was observed in microaggregates, our results confirms that microaggregates afford the most biochemical protection to associated SOM and can be considered a potential reservoir for $C$ sequestration (Six et al., 2002; Dungait et al., 2012). Notably, positive PE in microaggregates was initiated by high primer amendment. This finding becomes important when considering that glucose and other substances with similar availability are added over some days (or even weeks, e.g., in the rhizosphere and detritusphere) in the field. More microbial groups will be involved and stimulated because of longer input of available $C$ under field conditions (Mau et al., 2015). Therefore, we assume that PE under field conditions will be even stronger than that obtained under the controlled conditions with pulse glucose input in this study. This effect is harmful to the environment in the long term because it stimulates native soil C loss (Mau et al., 2015). In addition, frequent labile substrate input may lead to destabilization of the relative stable SOM pool (microaggregates in this study), which may cause more severe environmental harm.
4.3. The contribution of recent and old $C$ to $P E$ in aggregate size classes as dependent on primer amount

Partitioning of $\mathrm{C}$ sources revealed that a higher contribution of recent $\mathrm{C}_{4}-\mathrm{C}$ to $\mathrm{CO}_{2}$ efflux and microbial biomass, and a lower contribution to DOC, was independent of glucose levels and aggregate size classes (Figs. 2-4). These results clearly illustrate the rapid uptake of easily available substrates by microorganisms (Bol et al., 2009; Fischer et al., 2010) and so the low contribution of recent $\mathrm{C}$ to the DOC pool. In the same field, one year after conversion, $27 \%$ of recent $\mathrm{C}_{4}$-derived $\mathrm{C}$ was observed in $\mathrm{CO}_{2}$ fluxes, while this level was $5 \%$ in bulk soil, which indicates that the recently introduced $\mathrm{C}_{4}-\mathrm{C}$ in the soil was more available for microorganisms than old $C_{3}-C$ (Pausch and Kuzyakov, 2012).

The observation that there is more primed $\mathrm{CO}_{2}$ from recent $\mathrm{C}_{4}-\mathrm{C}$ than old $\mathrm{C}_{3}-\mathrm{C}$ under low glucose level (Fig. 8) is in line with previous isotope tracer studies, which demonstrated that more recent fresh plant-derived $C$ was initially incorporated in larger macroaggregates ( $>2 \mathrm{~mm}$ ) (Tian et al., 2013a). This effect can be promoted by the presence of Lumbricid earthworms (Bossuyt et al., 2005; Yavitt et al., 2015), which were abundant at the study site. Therefore, microorganisms preferentially use recent plant material consisting of relatively labile organic matter (Kramer and Gleixner, 2008; Salomé et al., 2010; Tian et al., 2013b). The high glucose stimulated the decomposition of old $\mathrm{C}_{3}-\mathrm{C}$ in macroaggregates that contributed $66.7 \%$ to the total PE over 49 days in larger macroaggregates $(>2 \mathrm{~mm})$ and $57.8 \%$ in aggregates of $2-0.25 \mathrm{~mm}$. This showed that mineralization of old SOC can be fueled by a larger amount of energy-rich substrates due to stimulation of higher enzyme production to meet microbial nutrient demands (Paterson et al, 2007) or higher bacterial diversity (Mau et al., 2015). However, the relative contribution of recent $\mathrm{C}_{4}-\mathrm{C}$ in primed $\mathrm{CO}_{2}$ increased from macroaggregates (37.8\%) to microaggregates (100\%) after high glucose input, suggesting that it was still not sufficient to trigger the 
decomposition of old SOM in microaggregates. Overall, our findings agree well with observations that the biochemical recalcitrance of SOM is proportional to decreasing aggregate size class (Poirier et al., 2005; Sohi et al., 2005; Zimmermann et al., 2007) and that large amounts of $C$ with old radiocarbon ages occur in association with size fractions < $0.02 \mathrm{~mm}$ (Marschner et al., 2008).

\section{Conclusions}

Aggregate size has a fundamental effect on the sources of $\mathrm{CO}_{2}$ released and the PE. The quantity of primer available is an important factor influencing the intensity of mineralized $C$ sources in PE with in the aggregate size classes. At the end of the incubation, positive PE at a low glucose level was induced only in large macroaggregates ( $>2 \mathrm{~mm}$ ). With increasing primer amount, positive PE was initiated in both large and small macroaggregates ( $>2$ and $2-0.25 \mathrm{~mm})$ and also in microaggregates $(<0.25 \mathrm{~mm})$. High primer amounts increased the contribution of old $\mathrm{C}_{3}$-derived $\mathrm{C}$ to primed $\mathrm{CO}_{2}$ in macroaggregates $(>0.25 \mathrm{~mm})$. Future studies are required to investigate how the soil microbial community structure and the PE sources change under the influence of aggregate size classes and primer addition.

\section{Acknowledgments}

We thank Major Program of National Natural Science Foundation of China (Grant No. 31420103917) and National Natural Science Foundation of China (Grant No. 31400460 and 30290221) for generous financial support. The contribution of EB was supported by Russian Scientific Foundation (project No. 14-14-00625). The authors also thank the China Scholarship Council for providing funding to Jing Tian to pursue her study in Germany and center for stable isotope research and analysis (KOSI) at university of Göttingen for ${ }^{13} \mathrm{C}$ analyses. We also thank the editor and two anonymous reviewers for their helpful comments that helped us to greatly improve the manuscript.

\section{Appendix A. Supplementary data}

Supplementary data related to this article can be found at http:// dx.doi.org/10.1016/j.soilbio.2016.03.013.

\section{References}

Besnard, E., Chenu, C., Balesdent, J., Puget, P., Arrouays, D., 1996. Fate of particulate organic matter in soil aggregates during cultivation. Eur. J. Soil Sci. 47, 495-503.

Blagodatskaya, E.V., Anderson, T.-H., 1999. Adaptive responses of soil microbia communities under experimental acid stress in controlled laboratory studies. Appl. Soil Ecol. 11, 207-216.

Blagodatskaya, E.V., Blagodatsky, S.A., Anderson, T.H., Kuzyakov, Y., 2007. Priming effects in chernozem induced by glucose and $\mathrm{N}$ in relation to microbial growth strategies. Appl. Soil Ecol. 37, 95-105.

Blagodatskaya, E., Yuyukina, T., Blagodatsky, S., Kuzyakov, Y., 2011. Three-sourcepartitioning of microbial biomass and of $\mathrm{CO}_{2}$ efflux from soil to evaluate mechanisms of priming effects. Soil Biol. Biochem. 43, 778-786.

Blagodatskaya, E., Khomyakov, N., Myachina, O., Bogomolova, I., Blagodatsky, S., Kuzyakov, Y., 2014. Microbial interactions affect sources of priming induced by cellulose. Soil Biol. Biochem. 74, 39-49.

Blagodatskaya, E., Kuzyakov, Y., 2008. Mechanisms of real and apparent priming effects and their dependence on soil microbial biomass and community structure: critical review. Biol. Fertil. Soils 45, 115-131.

Bol, R., Poirier, N., Balesdent, J., Gleixner, G., 2009. Molecular turnover time of soil organic matter in particle-size fractions of an arable soil. Rapid Commun. Mass Spectrom. 23, 2551-2558.

Bossuyt, H., Six, J., Hendrix, P.F., 2005. Protection of soil carbon by microaggregates within earthworm casts. Soil Biol. Biochem. 37, 251-258.

Bremer, E., Kuikman, P., 1994. Microbial utilization of C-14 [U]glucose in soil is affected by the amount and timing of glucose additions. Soil Biol. Biochem. 26, $511-517$.

Bremer, E., van Kessel, C., 1990. Extractability of microbial ${ }^{14} \mathrm{C}$ and ${ }^{15} \mathrm{~N}$ following additions of variable rates of labeled glucose and $\left(\mathrm{NH}_{4}\right)_{2} \mathrm{SO}_{4}$ to soil. Soil Biol.
Biochem. 22, 707-713.

Clarholm, M., 1985. Interactions of bacteria, protozoa and plants leading to mineralization of soil nitrogen. Soil Biol. Biochem. 17, 181-187.

Coleman, D.C., 1994. The microbial loop concept as used in terrestrial soil ecology studies. Microb. Ecol. 28, 245-250.

Connin, S.L., Feng, X., Virginia, R.A., 2001. Isotopic discrimination during long-term decomposition in an arid land ecosystem. Soil Biol. Biochem. 33, 41-51.

Creamer, C.A., Jones, D.L., Baldock, J.A., Farrell, M., 2014. Stoichiometric controls upon low molecular weight carbon decomposition. Soil Biol. Biochem. 79, 50-56.

Crow, S.E., Sulzman, E.W., Rugh, W.D., Bowden, R.D., Lajtha, K., 2006. Isotopic analysis of respired $\mathrm{CO}_{2}$ during decomposition of separated soil organic matter pools. Soil Biol. Biochem. 38, 3279-3291.

Denef, K., Zotarelli, L., Boddey, R.M., Six, J., 2007. Microaggregate-associated carbon as a diagnostic fraction for management-induced changes in soil organic carbon in two oxisols. Soil Biol. Biochem. 39, 1165-1172.

Derrien, D., Plain, C., Courty, P.-E., Gelhaye, L., Moerdijk-Poortvliet, T.C.W., Thomas, F., Versini, A., Zeller, B., Koutika, L.-S., Boschker, H.T.S., Epron, D., 2014. Does the addition of labile substrate destabilise old soil organic matter? Soil Biol. Biochem. 76, 149-160.

Dorodnikov, M., Blagodatskaya, E., Blagodatsky, S., Marhan, S., Fangmeier, A., Kuzyakov, Y., 2009. Stimulation of microbial extracellular enzyme activities by elevated $\mathrm{CO}_{2}$ depends on soil aggregate size. Glob. Change Biol. 15, 1603-1614.

Drury, C.F., Yang, X.M., Reynolds, W.D., Tan, C.S., 2004. Influence of crop rotation and aggregate size on carbon dioxide production and denitrification. Soil Tillage Res. 79, 87-100.

Dungait, J.A.J., Hopkins, D.W., Gregory, A.S., Whitmore, A.P., 2012. Soil organic matter turnover is governed by accessibility not recalcitrance. Glob. Change Biol. 18, 1781-1796.

Elliott, E.T., 1986. Aggregate structure and carbon, nitrogen, and phosphorus in native and cultivated soils. Soil Sci. Soc. Am. J. 50, 627-633.

Fischer, H., Ingwersen, J., Kuzyakov, Y., 2010. Microbial uptake of low-molecularweight organic substances out-competes sorption in soil. Eur. J. Soil Sci. 61, 504-513.

Fontaine, S., Barot, S., Barre, P., Bdioui, N., Mary, B., Rumpel, C., 2007. Stability of organic carbon in deep soil layers controlled by fresh carbon supply. Nature $450,277-280$

Fonte, S.J., Nesper, M., Hegglin, D., Velásquez, J.E., Ramirez, B., Rao, I.M., Bernasconi, S.M., Bünemann, E.K., Frossard, E., Oberson, A., 2014. Pasture degradation impacts soil phosphorus storage via changes to aggregateassociated soil organic matter in highly weathered tropical soils. Soil Biol. Biochem. 68, 150-157.

Green, V.S., Cavigelli, M.A., Dao, T.H., Flanagan, D.C., 2005. Soil physical properties and aggregate-associated $\mathrm{C}, \mathrm{N}$ and $\mathrm{P}$ distributions in organic and conventional cropping systems. Soil Sci. 170, 822-831.

Gregorich, E.G., Kachanoski, R.G., Voroney, R.P., 1989. Carbon mineralizationin soil size fractions after various amounts of aggregate distribution. J. Soil Sci. 40, 649-659.

Guggenberger, G., Elliott, E.T., Frey, S.D., Six, J., Paustian, K., 1999. Microbial contributions to the aggregation of a cultivated grassland soil amended with starch. Soil Biol. Biochem. 31, 407-419.

Gunina, A., Kuzyakov, Y., 2014. Pathways of litter C by formation of aggregates and SOM density fractions: implications from ${ }^{13} \mathrm{C}$ natural abundance. Soil Biol. Biochem. 71, 95-104.

Hamer, U., Marschner, B., 2005. Priming effects in soils after combined and repeated substrate additions. Geoderma 128, 38-51.

Hartley, I., Heinemeyer, A., Ineson, P., 2007. Effects of three years of soil warming and shading on the rate of soil respiration: substrate availability and not thermal acclimation mediates observed response. Glob. Change Biol. 13, $1761-1770$.

Hill, P.W., Farrar, J.F., Jones, D.L., 2008. Decoupling of microbial glucose uptake and mineralization in soil. Soil Biol. Biochem. 40, 616-624.

Keiblinger, K.M., Hall, E.K., Wanek, W., Szukics, U., Hämmerle, I., Ellersdorfer, G., Böck, S., Strauss, J., Sterflinger, K., Richter, A., Zechmeister-Boltenstern, S., 2010. The effect of resource quantity and resource stoichiometry on microbial carbonuse-efficiency. FEMS Microbiol. Ecol. 73, 430-440.

Kimura, S.D., Melling, L., Goh, K.J., 2012. Influence of soil aggregate size on greenhouse gas emission and uptake rate from tropical peat soil in forest and different oil palm development years. Geoderma 185, 1-5.

Kramer, C., Gleixner, G., 2008. Soil organic matter in soil depth profiles: distinct carbon preferences of microbial groups during carbon transformation. Soil Biol. Biochem. 40, 425-433.

Kramer, S., Marhan, S., Ruess, L., Armbruster, W., Butenschoen, O., Haslwimmer, H., Kuzyakov, Y., Pausch, J., Scheunemann, N., Schoene, J., Schmalwasser, A., Totsche, K.U., Walker, F., Scheu, S., Kandeler, E., 2012. Carbon flow into microbial and fungal biomass as a basis for the belowground food web of agroecosystems. Pedobiologia 55, 111-119.

Kuzyakov, Y., 2010. Priming effect: interactions between living and dead organic matter. Soil Biol. Biochem. 42, 1363-1371.

Kuzyakov, Y., Bol, R., 2006. Sources and mechanisms of priming effect induced in two grassland soils amended with slurry and sugar. Soil Biol. Biochem. 38, $747-758$.

Li, J.H., Yang, Y.J. Li, B.W. Li, W.J., Wang, G., Knops, J.M.H., 2014. Effects of nitrogen and phosphorus fertilization on soil carbon fractions in alpine meadows on the Qinghai-Tibetan Plateau. PLoS ONE 9, e103266. 
Malik, A., Blagodatskaya, E., Gleixner, G., 2013. Soil microbial carbon turnover decreases with increasing molecular size. Soil Biol. Biochem. 62, 115-118.

Marschner, B., Brodowski, S., Dreves, A., Gleixner, G., Gude, A., Grootes, P.M., Hamer, U., Heim, A., Jandl, G., Ji, R., Kaiser, K., Kalbitz, K., Kramer, C., Leinweber, P., Rethemeyer, J., Schäffer, A., Schmidt, M.W.I., Schwark, L. Wiesenberg, G.L.B., 2008. How relevant is recalcitrance for the stabilization of organic matter in soils? J. Plant Nutr. Soil Sci. 171, 91-110.

Mary, B., Fresneau, C., Morel, J.L., Mariotti, A., 1993. C and N cycling during decomposition of root mucilage, roots and glucose in soil. Soil Biol. Biochem. 25, 1005-1014.

Mau, R.L., Liu, C.M., Aziz, M., Schwartz, E., Dijkstra, P., Marks, J.C., Price, L.B., Keim, P., Hungate, B.A., 2015. Linking soil bacterial biodiversity and soil carbon stability. ISME J. 9, 1477-1480.

Mutuo, P.K., Shepherd, K.D., Albrecht, A., Cadisch, G., 2006. Prediction of carbon mineralization rates from different soil physical fractions using diffuse reflectance spectroscopy. Soil Biol. Biochem. 38, 1658-1664.

Negassa, W.C., Guber, A.K., Kravchenko, A.N., Marsh, T.L., Hildebrandt, B., Rivers, M.L., 2015. Properties of soil pore space regulate pathways of plant residue decomposition and community structure of associated bacteria. PLoS ONE 10 (4), e0123999.

Ngao, J., Cotrufo, M.F., 2011. Carbon isotope discrimination during litter decomposition can be explained by selective use of substrate with differing $\delta^{13} \mathrm{C}$. Biogeosciences Discuss. 8, 51-82.

Nguyen, C., Guckert, A., 2001. Short-term utilisation of ${ }^{14} \mathrm{C}-[\mathrm{U}]$ glucose by soil microorganisms in relation to carbon availability. Soil Biol. Biochem. 33, 53-60.

Ohm, H., Hamer, U., Marschner, B., 2007. Priming effects in soil size fractions of a podzol Bs horizon after addition of fructose and alanine. J. Plant Nutr. Soil 170, 551-559.

Otten, W., Hall, D., Harris, K., Ritz, K., Young, I.M., Gilligan, C.A., 2001. Soil physics, fungal epidemiology and the spread of Rhizoctonia solani. New Phytol. 151, $459-468$.

Paterson, E., Gebbing, T., Abel, C., Sim, A., Telfer, G., 2007. Rhizodeposition shapes rhizosphere microbial community structure in organic soil. New Phytol. 173, 600-610.

Paterson, E., Sim, A., 2013. Soil-specific response functions of organic matter mineralization to the availability of labile carbon. Glob. Change Biol. 19, $1562-1571$.

Pausch, J., Kuzyakov, Y., 2012. Soil organic carbon decomposition from recently added and older sources estimated by $\delta^{13} \mathrm{C}$ values of $\mathrm{CO}_{2}$ and organic matter. Soil Biol. Biochem. 55, 40-47.

Poirier, N., Sohi, S., Gaunt, J.L., Mahieu, N., Randall, E.W., Powlson, D.S. Evershed, R.P., Poirier, N., Sohi, S., Gaunt, J.L., Mahieu, N., Randall, E.W., Powlson, D.S., Evershed, R.P., 2005. The chemical composition of measurable soil organic matter pools. Org. Geochem. 36, 1174-1189.

Rabbi, S.M.F., Wilson, B.R., Lockwood, P.V., Daniel, H., Young, I.M., 2014. Soil organic carbon mineralization rates in aggregates under contrasting land uses. Geoderma 216, 10-18.

Saggar, S., Parshotam, A., Hedley, C., Salt, G. $1999 .{ }^{14}$ C-labelled glucose turnover in New Zealand soils. Soil Biol. Biochem. 31, 2025-2037.

Salomé, C., Nunan, N., Pouteau, V., Lerch, T.Z., Chenu, C., 2010. Carbon dynamics in topsoil and in subsoil may be controlled by different regulatory mechanisms. Glob. Change Biol. 16, 416-426.
Schneckenberger, K., Demin, D., Stahr, K., Kuzyakov, Y., 2008. Microbial utilization and mineralization of [14]C glucose added in six orders of concentration to soil. Soil Biol. Biochem. 40, 1981-1988.

Seech, A.G., Beauchamp, E.G., 1988. Denitrification in soil aggregates of different sizes. Soil Sci. Soc. Am. J. 52, 1616-1621.

Sey, B.K., Manceur, A.M., Whalen, J.K., Gregorich, E.G., Rochette, P., 2008. Small-scale heterogeneity in carbon dioxide, nitrous oxide and methane production from aggregates of a cultivated sandy-loam soil. Soil Biol. Biochem. 40, 2468-2473.

Six, J. Elliott, E.T., Paustian, K., 2000. Soil macroaggregate turnover and microaggregate formation: a mechanism for $\mathrm{C}$ sequestration under no-tillage agriculture. Soil Biol. Biochem. 32, 2099-2103.

Six, J., Conant, R.T., Paul, E.A., Paustian, K., 2002. Stabilization mechanisms of soil organic matter: implications for C-saturation of soils. Plant Soil 241, 155-176.

Six, J., Paustian, K., 2014. Aggregate-associated soil organic matter as an ecosystem property and a measurement tool. Soil Biol. Biochem. 68, A4-A9.

Sohi, S., Mahieu, N., Powlson, D.S., Madari, B., Smittenberg, R.H., Gaunt, J.L., Sohi, S, Mahieu, N., Powlson, D.S., Madari, B., Smittenberg, R.H., Gaunt, J.L., 2005. Investigating the chemical characteristics of soil organic matter fractions suitable for modeling. Soil Sci. Soc. Am. J. 69, 1248-1255.

Stevenson, F.J., 1994. Humus Chemistry: Genesis, Composition, Reactions. John Wiley \& Sons, New York, p. 496.

Tian, J., Pausch, J., Fan, M.S., Li, X.L., Tang, Q.Y., Kuzyakov, Y., 2013a. Allocation and dynamics of assimilated carbon in rice-soil system depending on water management. Plant Soil 363, 273-285.

Tian, J., Dippold, M., Pausch, J., Blagodatskaya, E., Fan, M., Li, X., Kuzyakov, Y., 2013b. Microbial response to rhizodeposition depending on water regimes in paddy soils. Soil Biol. Biochem. 65, 195-203.

Tian, J., Pausch, J., Yu, G., Blagodatskaya, E., Gao, Y., Kuzyakov, Y., 2015. Aggregate size and their disruption affect ${ }^{14} \mathrm{C}$-labeled glucose mineralization and priming effect. Appl. Soil Ecol. 90, 1-10.

Vance, E.D., Brookes, P.C., Jenkinson, D.S., 1987. An extraction method for measuring soil microbial biomass C. Soil Biol. Biochem. 19, 703-707.

Von Lützow, M., Kögel-Knabner, I., Ekschmitt, K., Flessa, H., Guggenberger, G., Matzner, E., Marschner, B., 2007. SOM fractionation methods: relevance to functional pools and to stabilization mechanisms. Soil Biol. Biochem. 39, 2183-2207.

Werth, M., Kuzyakov, Y., 2010. ${ }^{13} \mathrm{C}$ fractionation in transformations at the interface between roots, microorganisms, and soil: a review and synthesis. Soil Biol. Biochem. 42, 1372-1384.

Wu, J., Joergensen, R.G., Pommering, B., Chaussod, R., Brookes, P.C., 1990. Measurement of soil microbial biomass $\mathrm{C}$ by fumigation-extraction - an automated procedure. Soil Biol. Biochem. 22, 1167-1169.

Yavitt, J.B., Fahey, T.J., Sherman, R.E., Groffman, P.M., 2015. Lumbricid earthworm effects on incorporation of root and leaf litter into aggregates in a forest soil, New York State. Biogeochemistry 125, 261-273.

Zhang, H.J., Ding, W.X., He, X.H., Yu, H.Y., Fan, J.L., Liu, D.Y., 2014. Influence of 20-year organic and inorganic fertilization on organic carbon accumulation and microbial community structure of aggregates in an intensively cultivated sandy loam soil. Plos One 9, e92733.

Zimmermann, M., Leifeld, J., Schmidt, M.W.I., Smith, P., Fuhrer, J., 2007. Measured soil organic matter fractions can be related to pools in the RothC model. Eur. J. Soil Sci. 58, 658-667. 